\title{
Reception of law as a form of cultural interaction
}

\author{
Yulia Evgenievna Voronina* \\ RUDN University, Law Institute, Moscow, Russia
}

\begin{abstract}
The study's objective is to identify factors contributing to the positive results of legal reception and generalize the concept of legal reception, revealing the close relationship of law with the culture. During the research, various scientific approaches and methods of knowledge contributed to the achievement of the intended objective. The research is based on dialectical, systemic methods and the comparative legal approach. The result of the study was the conclusion that the result of intercultural interaction is not always favorable and can have both positive and negative consequences: when the national legal system becomes inconsistent, illogical, loses the character of self-execution, up to the fatal outcome - the destruction of the legal culture of society. As the most important condition for the successful reception of law, the authors highlight the compatibility of the cultures of the donor country and the recipient country (interacting cultures). It is argued that the formation of a single global cultural, legal space does not reflect the objectively existing patterns of development of societies, and the incompatibility of different types of legal cultures is the main factor preventing the creation of global legal order in general and hindering the success of the reception of law in particular. The novelty of the research is determined by the fact that the reception of law is one of the forms of intercultural interaction and plays a significant role in the mutual penetration of legal cultures. Although the topic is one of the most popular for domestic and foreign legal science, as a rule, its study is reduced to the description of the facts of reception, in most cases of Roman law, and the number of general theoretical studies of this issue is insufficient.
\end{abstract}

Keywords: acculturation, globalization, cultural influence, legal culture

\section{Introduction}

The study's background is due to the fact that the current stage of social development is characterized by increasingly close interaction and interdependence of individual states and regions that form the world community. National legal systems are in constant dialogue, and the legal culture of one society is enriched by elements of other legal cultures [1-4]. The reception of law is an objective process inherent in any society that is not in a state of artificial isolation [5].

\footnotetext{
* Corresponding author: 1042200146@,rudn.university
} 
The purpose and objectives of the study are to identify factors contributing to the positive results of legal reception and generalize the concept of legal reception, revealing the close relationship of law with the culture. The study's hypothesis is based on the fact that the development of legal cultures occurs in at least three directions. First, they are capable of self-development. Second, legal culture is capable of modernizing itself by interacting with other legal cultures. Finally, attempts are being made to unify the law on a global scale.

\section{Methods}

The research was based on dialectical and systematic methods that allowed assessing the reception of law as a set of interrelated processes and factors and considering the law in its constant development and interaction with other social phenomena. A comparative legal approach was used to compare the elements of different legal cultures.

\section{Results}

The study concluded that the result of cross-cultural interaction is not always favorable and can have both positive and negative consequences: when the national legal system becomes inconsistent, illogical, loses the character of self-fulfillment, up to the fatal outcome - the destruction of the legal culture of society. As the most important condition for the successful reception of law, the authors highlight the compatibility of the cultures of the donor country and the recipient country (interacting cultures).

The formation of a single global cultural, legal space does not reflect the objectively existing patterns of development of societies, and the incompatibility of different types of legal cultures is the main factor preventing the creation of global legal order in general and hindering the success of the reception of law in particular.

\section{Discussion}

Often, legal acculturation is reduced to a form of reception of law [6], which is a large-scale borrowing and perception by a state of law that is the product of other societies and historical eras.

Russian and foreign researchers have different approaches to the definition of the reception of law. Domestic authors [7, 8] speak about the voluntary perception of foreign normative material. Western European literature also recognizes the forced legal assimilation, the imposition of the legal system or its individual elements of one state on another. At the same time, voluntary borrowing is usually carried out at a deeper level than in the case of expansion. The adaptation of perceived models occurs organically, without meeting resistance at the level of legal awareness. This is due to the continuity, the objective connection between national legal systems, the common socio-economic conditions of development, the similarity of cultural and political-legal values. Thus, for example, during the colonial era, attempts to replace the law of the colonies, syncretistic with the "world order", with European law proved unsuccessful. The legal norms were abolished there, and the institutions deprived of power continued to operate, and in the minds of people had more authority than the official authorities. Ignoring the cultural identity of individual peoples significantly complicates the process and can lead to the fact that society will not adapt to the borrowed elements, and they will be rejected.

The modern multicultural world is characterized by the interpenetration of cultures [9], but the possibilities of legal receptions are not unlimited and have their limits [10] and are 
primarily due to the compatibility of legal cultures [11]. The culture of the recipient country should be compatible with the content of the borrowed material.

The probability of successful reception of the law is increased if the transferred legal elements are introduced into people's legal space and behavior with a different culture gradually and unobtrusively. The desire for their early implementation does not contribute to high-quality assimilation. In assessing the prospects for the reception of law, we should not limit ourselves to the consideration of the legislation but should pay particular attention to the actual legal order and legal culture as a context for legal innovation, since often legislation in "non-Western" countries has a rather limited scope of application and remains at the level of declarations and good wishes. A much more important role is played by the values and principles on which the legal culture of the recipient is built [12].

Every society is unique. Its choice of a particular path of development is influenced by the decisions made in the past, and the challenges faced. This fully applies to the law. The experience, to a large extent, limits the current realistic possibilities for law reception and legal reform. Furthermore, this determines that the borrowing of norms between the AngloSaxon system of law and the continental system is much more difficult than between systems with a similar legal culture [13].

An equally important factor contributing to the achievement of positive results of the reception of law should be considered the language factor. The language reflects the mentality, ideology, values, traditions, and customs of the native speakers of this language. Thus, when translating legal texts, one may encounter many linguistic and cultural problems due to the collision of two different legal systems and legal cultures. Like any other legal culture, the Islamic legal culture is replete with terms and principles that are considered an important part of the legal Arabic language and, consequently, of Islamic jurisprudence. Such Islamic cultural and legal concepts cannot be correctly interpreted unless the translator is fully familiar with Islamic law and Islamic legal culture [14] since they are due to the uniqueness of the language and culture of a given society.

Professor Zhang Hong Li notes the overall positive role of the mutual influence of representatives of the two cultures, provided that their identity is preserved [15]. However, in practice, the adoption of foreign legal norms and institutions is not always accompanied by progress in the law of the recipient state. Legal borrowing is not equivalent to legal development. There may be situations in which borrowed elements of an alien legal system will be rejected. For example, the attempt by the United Nations to introduce the institution of human rights and freedoms as a global one, considered a criterion of globalization, has resulted in its rejection in some countries, including in the most populous country in the world - China.

The practice of using perceived elements can also generate a lot of undesirable consequences, since together with the planned material, it is automatically borrowed, and the recipient state may not be ready to accept it [16]. Or even encounter a situation in which the social relations that regulate the norms being reciprocated have not yet taken shape in the society. This kind of additional unscheduled elements leads to a deviation from the original intention of the recipient.

In addition, the perceived legal model may undergo a major change. Law is a "tracing" of the existing relations in society; it reflects the nature of the culture of the people and the era of its history [17]. Under the influence of socio-cultural, economic and political factors, the legal structure will undergo significant changes and will sometimes fundamentally differ from its counterpart in the donor state.

At the same time, mechanical copying of elements of foreign legal systems should be avoided since this threatens to destroy national identity and is associated with a high probability of destroying the legal culture of the recipient society. An individual approach to each case is required. To modernize the state and the legal system, it is necessary to 
create a flexible reception mechanism that considers public needs at a specific historical stage, taking into account the following factors: legal thinking, legal culture, and legal mentality. Only reasonable and justified borrowing will serve to enrich the national legal system and meet the needs dictated by the process of globalization [18].

\section{Conclusion}

Being a part of the general culture, the law is in constant intercultural interaction, and the ambiguity of such influence stems from the scale of borrowing. On the one hand, in today's world intercultural interaction often erases existing legal and cultural differences, the universalization and standardization of law; on the other hand, there is an increase in conflict, difficult situations, both within national legal systems and their mutual influence. This can lead to critical consequences, including destroying the recipient culture if an attempt is made to change its system-forming core (principles, values, views on the social significance of law) [19]. Today, there is an imbalance in the interpenetration of cultures, which results in the dominance of Western-style mass culture in the world; that is, we are talking about a "dictate of power", and not a harmonious union or "unity of diversity" [20]. However, along with this trend, there is a revival of national consciousness as a kind of protection against such interference and the destructive influence of globalization. Ultimately, such processes hinder forming a single global cultural legal space since intercultural interaction reveals its limits. The incompatibility of different legal cultures is the main factor that hinders the creation of a certain global legal order in general and counteracts the successful implementation of the reception of law in particular. In other words, despite the constant legal dialogue of cultures, historical self-identification, the preservation of value worldviews, and the continuity of traditions remain important elements of public life.

\section{References}

1. L. Brang, Global Constit. 9(1), 117-154 (2020)

2. N. Perez, Ethnic and Racial Stud., 44(11), 1995-2015 (2020). https://doi.org/10.1080/01419870.2020.1807036

3. M. Zakharova, V. Przhilenskiy, BRICS Law J. 5(2), 4-23 (2018)

4. A. Amend-Traut, Glossae: Europ. J. Legal Hist. 15, 32-49 (2018)

5. N. El Hage, Acculturation, pluralism and legal change in Arab countries, in A. Cayol, Zh. Sairambaeva, P. Chabal (eds.), The challenge of change for the legal and political systems of Eurasia: The impact of the new silk road, 33-46 (Berlin, Bern, Bruxelles, New York, Oxford, Warszawa, Wien, 2020). https://doi.org/10.3726/b16535

6. V.N. Kartashov, Bul. YarGU. Human. Ser. 2, 45 (2018)

7. V.A. Rybakov, Retseptsiya prava: obshcheteoreticheskie voprosy [Reception law: general theoretical issues] (Nauka, Omsk, 2009)

8. A.R. Gubaidullin, Bul. Kutafin Moscow State Law Univ. 4, 83 (2017). https://doi.org/10.17803/2311-5998.2017.32.4.081-090

9. S. Zinkovskii, T. Schastlivaya, D. Maslov, Opción, 35(22), 162-174 (2019)

10. V.A. Rybakov, Yuridicheskaya Tekhnika, 5, 23 (2011)

11. S.N. Kasatkin, Kulturnyi plyuralizm, parokialnost pravovykh ponyatii i retseptsiya inokulturnogo opyta [Cultural pluralism, the parochialism of legal concepts and the reception of foreign cultural experience. Contours of the future in the context of world 
cultural development], in 18th International Likhachev Sci. Readings, May 17-19, 503 (SPbGUP, Saint Petersburg, 2018)

12. L.V. Sokolskaya, Act. Probl. Rus. Law 8(45), 1587 (2014)

13. J. Husa, The Chinese J. Compar. Law, 2, 130 (2018). https://doi.org/10.1093/cjcl/cxy008

14. R.Y. Alwazna, Intern. J. Legal Discourse, 2, 307 (2017). https://doi.org/10.1515/ijld2017-0013

15. Ch. Hongli, Soc.: Philos., Hist., Cult. 1(69), 121 (2020). https://doi.org/10.24158/fik.2020.1.21

16. A.A.Vorotnikov, V.A. Marchenko, Bul. Saratov State Law Acad. 1(114), 14 (2017)

17. G.I. Muromtsev, Pravogenez i teoriya prava [Law genesis and theory of law], in M.V. Nemytina (ed.), Law - the phenomenon of civilization and culture, 2 (RUDN Publishing House, Moscow, 2020)

18. D.S. Nechaeva, Leningrad Legal J. 4(62), 56 (2020). https://doi.org/10.35231/18136230_2020_4_48

19. M. Van Hoek, News of Higher Edu. Instit. Juris. 6(317), 10 (2014)

20. Yu.Yu. Bugaenko, Bul. Peoples’ Friendship Univ. Rus. Ser.: Sociol. 1, 72 (2013) 